\title{
Teaching Strategies to Enhance Students' Creativity in English Profession Subject during the Covid-19 Pandemic
}

\author{
Diani Nurhajati \\ Universitas Nusantara PGRI Kediri, Indonesia \\ E-mail:dianihamzah@unpkediri.ac.id
}

Received: 24 July 2021; Revised: 15 November 2021; Accepted: 20 November 2021

\begin{abstract}
During the Covid-19 pandemic, the learning process must be carried on from home. In fact, all of the university graduates should be equipped with a number skills needed to face the Industrial Revolution 4.0. Therefore, lecturers are expected to find the solution to train the skills, including creativity. One of the solutions is selecting the right teaching strategy. The objective of the research was to describe the teaching strategies employed by the lecturer English Profession to promote creativity and explain the teaching strategies to enhance the students' creativity. This descriptive qualitative study took 60 students as the subjects. They were the students who took English Profession Subject at the Elementary School Education, University of Nusantara PGRI Kediri. The techniques of collecting data were observation checklist and questionnaire. The findings of the research show that the lecturer employed Project Based Learning in which the students were assigned to create some projects, namely video, game manual, and English book for elementary school students.
\end{abstract}

Keywords: English Profession; Project Based Learning; student creativity; teaching strategy;

\section{Introduction}

Currently the world is facing such a big problem because of a new virus called the corona virus or also known as COVID-19. Many people have been affected and even many people have died because this virus has spread throughout all regions in Indonesia. The impact felt by all citizens in Indonesia is not only in terms of health, but also in terms of economy and education. In addition, education in Indonesia must feel the same way that all schools must really do social distancing. They are not allowed to carry on face-to-face learning until an undetermined time. The Indonesian government does not allow any school to hold offline meetings in class. As a result, all of the school must take online learning as the latest solution so that students and teachers can continue to carry out learning activities.

The COVID-19 pandemic is a new challenge for teachers and lecturers. With the COVID-19 pandemic, the education must comply with the demands of the Industrial Revolu- tion Era 4.0, where some activities carried out in learning must rely heavily on digital technology. Changes and developments in the world are very rapid, so it is necessary to prepare adequate human resources with competent skills so that they are ready to adapt and be able to compete on a global scale. Empowerment and improvement of human resources through education is one of the keys to being able to follow the development of the Industrial Revolution 4.0.

In order to face the challenging condition, graduates of university must have a number of skills. According to National Standard, Directorate of Higher education (SN-Dikti), there are some elements of learning outcomes of higher education graduates must have, and they include attitudes and values, abilities, knowledge, and responsibilities/rights. It is stated in the background and objectives of the guidebook of independent campus program (Program Kampus Merdeka) that the independent learning program is designed and implemented properly, to be able to form students' hard and soft skills, this is 
intended to make students more prepared and relevant to the needs of the times. Lecturers have to equip students with skills well to be able to compete globally.

In this era, the skills to compete in the digital era is called $4 \mathrm{C}$, namely Creativity, Collaboration, Critical Thinking, and Communication. The $4 C^{\prime}$ 's are the most important 21 st century skills that students must have. According to Zubaidah (2018), creativity is the ability to create innovation or find new ways to solve problems. Collaboration means being able to collaborate, adapt to a team, and share roles to achieve goals. This means that someone can cooperate with other people. Critical Thinking is about the skill of thinking outside the brain, and it is all about solving problems. Lastly, communication is the skill of expressing ideas, questions and solutions in a good way.

Creativity is one of the $4 \mathrm{C}$ skills that students must have. These skills are a solution that can help students face the Industrial Revolution Era 4.0. In the Industrial Revolution Era 4.0 students were asked to be creative students. According to Sternberg (1999), creativity is the ability to produce work that is novel (i.e., original, unexpected) and appropriate (i.e., useful, adaptive to task constraints). Similarly, Hwang et al (2007) define creativity as the ability to solve problems or produce something useful and new. Furthermore, Saefudin (2012) said that creativity refers to "a product of the ability (creative thinking) to produce new ways or things in dealing with a problem or situation". The ability to think creatively is described by Torrance in Zubaidah (2018). He defined that creative thinking is the ability to formulate problems, make assumptions, generate new ideas, and communicate results.

These skills are completely new and original actions, both personally and culturally (Abdullah and Osman, 2010). Willingness of students to think about problems or challenges, share thoughts with others and listen to feedback, are some examples of creative thinking that students can demonstrate in their learning. In short, creativity is an important skill needed in the $21^{\text {st }}$ century in which students must create something by considering three perspectives, namely originality, novelty, and difference or seeing things from a different perspective.

English Profession is a subject provided by Elementary School Education Program, Faculty of Teacher Training, University of Nusan- tara PGRI Kediri. The learning outcome of the subject is that the students are able to select and develop materials for teaching English to elementary school students, and they are able to apply the English instruction at school. To reach the learning outcome, the lecturer implemented blended learning. This is in line with Panduan Penyusunan Kurikulum di Perguruan Tinggi (The Guidance of Curriculum Development for Higher Education) by Directorate of Higher Education the Ministry of Education and Culture 2020. It is stated that lecturers must apply blended learning (hybrid learning). It is a combination between conventional learning (face-to-face or direct meeting in the classroom) and online learning. The learning process must involve Information and Communication Technology.

There is a big challenge for lecturers during the pandemic. They have to develop students' soft skills, including creativity. In fact, the process of the teaching and learning must be carried out from home. The solution that they can do is selecting the right teaching strategies. Teaching strategies in this research involve teaching methods and learning activities. According to SNDikti, the examples of teaching methods are group discussion, case study and simulation, collaborative learning, cooperative learning, project based learning, and problem based learning. Learning activities includes lecturing, tutorial, seminar, practicum, etc.

Based on the observation, the lecturer of English Profession applied Project Based Learning as a medium to train students' creativity. She assigned the students to create a project that was writing an English student book for elementary school. According to Bell (2010) Project Based Learning (PBL) is an innovative approach to learning that teaches a multitude of strategies critical for success in the twenty-first century. Students drive their own learning through inquiry, as well as work collaboratively to research and create projects that reflect their knowledge. Krajcik \& Blumenfeld (2006, p. 317) also stated that Project Based Learning allows students to learn by doing and applying ideas. Students engage in real -world activities that are similar to the activities that adult professionals engage in.

PBL is an instructional strategy of empowering learners to pursue content knowledge on their own and demonstrate their understandings through a variety of presentation modes. Nurhajati (2017) states that PBL facilitates students to construct knowledge by producing the product 
based on their interest and individual difference. In short, this instructional strategy can facility students to develop their creativity.

There are some studies dealing with PBL and creativity. First, Syarifah and Emiliasari (2018) found that Project Based Learning helped the students create the projects through a process, such as thinking of ideas, experimenting, and failure. Another research that applied creativity by means of PBL by Ummah, In'am, and Azmi (2019) found improvement of students' creativity in completing the project of making mathematics learning media based on novelty aspect meets the good category. Furthermore, Nurhajati, Kencanawati, and Riwayatiningsih (2020) admitted that this teaching method helps the English teacher provide a series of teaching activities that improve students' critical thinking. In short PBL is a teaching model that useful to develop students'skills, including creativity.

Based on the explanation above, the researcher is interested to carry out a research that promote creativity in English Profession subject during Covid-19 Pandemic. The objective of the research was to describe the teaching strategies employed by the lecturer English Profession to promote creativity and explain the teaching strategies to enhance the students' creativity.

\section{Material and Method}

This is a descriptive qualitative research. It is a case study, which aims to describe the teaching strategies employed by the lecturer English Profession Subject to promote creativity at University of Nusantara PGRI Kediri. Besides, it also describes how the strategies enhance the students' creativity. The research was carried out in the even semester in the academic year 2020/2021. The subjects of the research were the lecturer of English Profession and 60 students who took the subject. They were from the eighth semester students of Elementary School Education Program, University of Nusantara PGRI Kediri. The techniques of collecting the data were observation during teaching and learning process and questionnaire. The results of the observation that is about the teaching strategies would be presented descriptively. The data related with students' creativity were collected using questionnaire and would be presented statistically.

\section{Results and Discussion}

This part presents the findings of the research. It can be reported that English Profession Subject is provided to prepare the graduates of Elementary School Education Program to an English teacher at elementary school level. They were introduced some theories dealing with friendly child learning English as the basis. It means the ways teaching English must be suitable with the learners. Since the learning process was during the Covid-19 pandemic, the lecturer applied blended learning in which the most of teaching and learning activities were carried out virtually. She used some applications, Zoom meeting, Edmodo, and WhatsApp. She shared the materials in Edmodo or WhatsApp before having synchronous meeting via Zoom every week. The synchronous meeting was carried out only 90 minutes due to the time allocation from free payment Zoom. If the students had problems, they could have asked via WhatsApp, either text, telephone, or video-call. Face-to-face meetings were carried out twice that was in the last two meetings. The aim of having face-to-face meeting was to give opportunity for the students to demonstrate teaching practice in front of the peers.

There were sixteen meetings in one semester for English Profession. The lecturer had made the preparation before she taught using blended learning. In the first meeting, she informed and explained to the students about the learning outcomes of the subject, the teaching strategies, the projects that they had to create, and the assessment. The preparation was written in the lesson plan and it was shared to the students in Edmodo.

\section{Teaching Strategies}

The teaching strategies can be classified into two; they are learning activities and teaching methods. The lecturer employed some learning activities, namely lecturing, and teaching practice. Firstly, teaching and learning process was done in order to present and explain important concepts or theories that the students must understand. It was done synchronously via Zoom meeting for the whole class. If some students had problems, they could have such a meeting using video call via WhatsApp. It was done to make the students expressed themselves freely. To have such a meeting, the lecturer usually had interactive conversation with the students in order to check their understanding on certain concepts. The second learning activity was teaching practice. The students were assigned to select and de- 
velop the materials in groups of three students. They also had to design the learning activities for elementary school students to teach listening and speaking. In this case, each group had to perform in class. The class was divided into two groups, the first group had a direct meeting in the class, while the other groups were assigned to develop student book to teach English at elementary school. It was done because of pandemic rule that the number of students who were able to meet in the class was only $50 \%$ of the total number.

The third, the teaching method applied by the lecturer was PBL. The lecturer assigned the students to create some projects, namely video of teaching vocabulary, manual to teach English using games, and English student book. Those projects had been informed to the students at the first meeting. The first project was done for middle test; the second project was done at the eleventh meeting; and the student book was assigned as the final project at the end of the semester. The students had to work in groups of three students.

There were some stages of PBL employed by the lecturer; they are selecting materials, planning, developing, and presenting. In the first stage, the lecturer made preparation the project that the students had to make. She divided the class into groups consisted of three students. She selected the example of the project to be shared with the students. She shared not only the examples, but also some sources in Edmodo, so the students could download them. The next stage, she informed and explained the project the students had to make via Zoom meeting. After that, the students discussed with the group about the concept and the plan of creating the project. Finally, each group had to present the creation with their peers via Zoom meeting in turns. The lecturer and other students gave feedback for the creation, and they revised the creation based on the feedback.

\section{The Students' Creativity}

Students' creativity in this research means a product of the ability (creative thinking) to produce new ways or things in dealing with a problem or situation. The products made by the students were video of teaching vocabulary, game manuals, and English student book. The first project was that the students have to create a video that demonstrate teaching English vocabulary using Total Physical Response to a number of elementary school students. The stu- dents had to select and develop the materials and design how to perform. Besides, they had to create a student worksheet to assess.

The second project was manuals to teach English using games. The students had to create certain games to put the language (vocabulary and expressions) in a real context of communication. The games must be easy to handle in the class. The manual consists of topic/sub-topic, language skill, learning objective, type of activity, language focus, teacher preparation, the steps, and the media for the game. To develop the manual the students had to select the materials based on the topic/sub-topic given. They had to formulate the learning objective that could be reached through the game. They had to choose the type of game, whether small group or classical game. After that, they wrote the preparation for teachers before carrying out the game, the rules, and the steps of the game. The last part, they had to provide the examples of media for the game.

The third project was an English book for elementary school. The students had to follow the format of book chapter given by the lecturer. The book consists of a number of chapter, and each chapter was developed by one group. Each chapter is developed to learn the four skills, listening, speaking, reading, and writing according to the given topic. However, the learning activity in the book focus on more oral cycle (listening and speaking). The learning activities for listening and speaking may vary in order to facilitate young learners to practice those skills in easy and fun ways. The other two skills are given to train elementary school students in reading aloud, spelling words, and arranging jumble words into simple sentences. For reading activity, there is a short simple text related with the topic. The number of sentence of the text is around ten sentences, and they use simple sentence structure. The content of the text is about the child experience and there must encourage them to do positive things, such as happiness, togetherness, healthy life, etc. At the beginning part of the chapter, there must be a greeting song, and in the last part of the chapter, there is a leave-taking song.

Based on the learning experience, the students were given a questionnaire asking whether they enhanced their creativity. The response from the students can reported:

a. The first indicator is about the teaching strategies of English Profession Subject enhance the students' creativity. It can be seen from the students' response, 55\% wrote strongly agree and $45 \%$ wrote agree, 
and no one wrote neutral, disagree, and strongly disagree.

b. The second indicator is about the process of creating video enhance the students' creativity. It can be seen from the students' response, $55 \%$ wrote strongly agree and $45 \%$ wrote agree, and no one wrote neutral, disagree, and strongly disagree.

c. The third indicator is about the process of creating manual for games enhance the students' creativity. It can be seen from the students' response, 53, 3\% wrote strongly agree and $46,7 \%$ wrote agree, and no one wrote neutral, disagree, and strongly disagree.

d. The fourth indicator is about process of creating English student book enhance the students' creativity. It can be seen from the students' response, $60 \%$ wrote strongly agree and $40 \%$ wrote agree, and no one wrote neutral, disagree, and strongly disagree.

In addition, the students were able to express their ideas dealing with the process of teaching and learning that enhance their creativity. The followings are three selected statements from the students dealing with the teaching strategy in English Profession.

Student 1: "I think the lecturer gave many chances for the students to more creative by creating some projects. Even though there were many assignments, the lecturer gave motivation and feedback to improve the quality of the products."

Student 2: "The teaching methods of the subject were simple, but joyful and interesting. They helped the students understand and learn the material easily. Besides the lecturer taught and trained the students to teach English to young learners suitable with the level of young learners. It encouraged them to be creative in teaching English. For example, using various techniques, games, storytelling, songs, etc."

Student 3: "The teaching methods that make us to creative were asking us to develop materials, prepare the steps of teaching, and perform in front of the class. After the performance, the lecturer and the other students gave feedback to improve the works."

From the findings above, it can be concluded that the teaching strategies employed by the lecturer of English Profession can enhance the students' creativity. The students responded positively towards the methods and the learning activities provided by the lecturer.

\section{Discussion}

This part presents the discussion of the research. Firstly, from the first part of the findings it was found out that the teaching strategies employed by the lecturer of English Profession enhanced the students' creativity. The teaching strategies cover learning activity and teaching methods. The lecturer carried out the learning process both synchronous and asynchronous learning using certain application. It is the only way to as the learning process was during the Covid-19 Pandemic. The teaching strategies are suitable with the ones stated in SN-Dikti (Panduan Penyusunan Kurikulum Pendidikan Tinggi di Era Industri 4.0 untuk Mendukung Merdeka Belajar-Kampus Merdeka, 2020:10). The learning activity chosen by the lecturer was PBL in which the students had to create some products. While the learning activities were lecturing, discussion, and presentation. Those strategies enhanced students' creativity, as they have to prepare the projects, create them, and perform.

Based on the products created by the students, the lecturer provided chances to be creative. To create video, manual, and English book the students must have creative ability to produce new things, to generate and communicate their ideas in new ways, It is in line with what Hwang et al (2007), Saefudin (2012), and Torrance in Zubaidah (2018). They believe that creative thinking is the ability to formulate problems, make assumptions, generate new ideas, and communicate results

The finding of this research is in line with some previous research. Firstly, Katz and Stupel (2015) found collaborative research task in mathematics promotes creativity and self-efficacy. PBL consists of many activities in which students have to cooperate with teams to create a project/product. Both learning activities have similarity, and they promote students' creativity. The other research done and Syarifah and Emiliasari (2018) indicates that students and teachers are comfortable with PBL and its assessment methodology, student feedback ensures that PBL can increase creativity. Furthermore, a study by Ummah, In'am, and Azmi (2019) proved that the application of PBL allows students to explore and can strengthen their creativity. Moreover, Setya- 
wan and Nurhajati (2019) admitted that PBL can be used to develop students' life skills and speaking ability. Finally, Setiawan, Puspitasari, and Baptista (2020) conclude that Project Based Learning can be used as a breakthrough to enhance High Order Thinking Skills, which cover the ability of analyzing, evaluating, and creating. From the findings of the previous research prove that PBL can enhance students" creativity.

Furthermore, the learning activities applied by the lecturer in this research were lecturing, discussion, presentation, and perform teaching practice. Those methods will be useless if the lecturer cannot integrate with the attitude, for example: she gave motivation and feedback (Student 1 and Student 2). This finding supports a research by Nurhajati and Widiarini (2014) that found teacher's behavior and attitude influence students' selfconfidence and motivation in learning. It is really needed to encourage students to be more creative. Besides, the methods help students understand the concepts and theories to be applied. There are some notes written by the students in applying the methods. They are relax atmosphere, enough examples and references, the real needs of the learners of elementary school, simple and uncomplicated materials, and feedback. Finally, it can be said selecting the right teaching strategies is very important as it will influence students' creativity. The skill is really needed by university graduates to face the tight global competition in the Industrial Revolution 4.0.

\section{Conclusion}

Creativity is an important skill needed in the Industrial Revolution 4.0. The skill must be developed by all lecturers to prepare the university graduates face the global competition. Even though learning process faces a problem dealing the Covid -19 pandemic, lecturers still can find the solution by having online learning. Based on the findings and discussion, it can be concluded that selecting the right teaching strategy can enhance students' creativity. The teaching strategies cover two things: they are learning activities and teaching method. The learning activities that encourage creativity are lecturing, discussion, presentation or teaching practice. the learning activities applied by the lecturer in this research were lecturing, discussion, presentation, and perform teaching practice. Those methods will be useless if the lecturer cannot integrate with the positive attitude, such as giving valuable feedback. The teaching method that enhance creativity Project Based Learning. This method provides many activities that encourage students to practice various soft skills, especially creativity.

\section{Suggestion}

Finally, it is suggested for other lecturers to find right teaching strategies to facilitate students develop their soft skills. For future research, they can focus on developing students' soft skills using different teaching methods stated in SN-Dikti, such as group discussion, case study and simulation, collaborative learning, cooperative learning, project based learning, and problem based learning.

\section{References}

Anitha, D., Jeyamala, C., \& Kavitha, D. (2018). Assessing and enhancing creativity in a laboratory course with project based learning. Journal of Engineering Education Transformations, 32 (2), 67-74. URL:

http://ischolar.info/index.php/ JEETRIT/article/view/178145/0

Bell, S. (2010) Project-Based Learning for the 21st Century: Skills for the Future, The Clearing House, 83:2, 39-43, DOI: 10.1080/00098650903505415

Direktorat Pendidikan Tinggi Kementrian Pendidikan dan Kebudayaan (2020). Panduan Penyusunan Kurikulum Pendidikan Tinggi di Era Industri 4.0 untuk Mendukung Merdeka Belajar Kampus Merdeka.

Hwang, W.Y., Chen, N.S., Dung, J.J., dan Yang, Y. 2007. Multiple Representation Skills and Creativity Effects on Mathematical Problem Solving using a Multimedia Whiteboard System. International Forum of Educational Technology \& Society Journals. URL: https://www.ds.unipi.gr/et\&s/ journals/10 2/17.pdf

Jahnke, I., Haertel, T., \& Wildt, J. (2017). Teachers' conceptions of student creativity in higher education. Innovations in Education and Teaching International, 54(1), 87-95. doi.org/10.1080/14703297.2015.1088 396

Katz, S., \& Stupel, M. (2015). Promoting Creativity and Self-Efficacy of Elementary Students through a Collaborative Research Task in Mathematics: A Case 
Study. Journal of Curriculum and Teaching, 4(1), 68-82.

Krajcik, J., \& Blumenfeld, P. C. (2006). Projectbased learning. In R. K. Sawyer (Ed.), The Cambridge handbook of the learning sciences (pp. 317 - 334). New York: Cambridge University Press.

Nurcahya, N., \& Sugesti, I. (2020). Enhancing Students' Writing Ability and Creativity through Project Based Learning on Greeting Card. ETERNAL (English Teaching Journal), 11(1). URL:

http://journal.upgris.ac.id/index.php/ eternal/article/view/6063/3157

Nurhajati, D. and Widiarini (2014). Enhancing Students' Self-Confidence through Teacher's Behaviour Change on Lesson Study Program for TEYL 1. Proceedings Reflective Educators and Professionals of Learning, November 25 - 28, 2014. Pp. $540-$ 545.

Nurhajati, D. (2017). Creating English Student Book through Project Based Learning in TEYL Subject, Advances in Social Science, Education and Humanities Research, volume 145. Pp. 66-69. Atlatic Press. https://www.atlantis-press.com/ proceedings/iconelt-17/25888985

Nurhajati, D., Kencanawati, D., \& Riwayatiningsih, R. (2020). Enhancing Critical Thinking in Speaking Skill through Sekawan-P. Journal of English Teaching and Research, 5(1), 92-102. URL:

https://ojs.unpkediri.ac.id/index.php/ inggris/article/view/14370

Saefudin. A. A. (2012). Pengembangan Kemampuan Berpikir Kreatif Siswa Dalam Pembelajaran Matematika Dengan Pendekatan Pendidikan Matematika Realistik Indonesia (PMRI). AlBidāyah, Vol 4 No. 1, Juni 2012: 37-48 Available: https:// media.neliti.com/media/ publications/284564-pengembangankemampuan-berpikir-kreatif-24d08653.pdf

Setiawan, R. Y., Puspitasari, R. D., \& Baptista, G. (2020). Projet-Based Learning: Terobosan Baru dalam Melatih HOTs pada Keterampilan Speaking Mahasiswa. Briliant: Jurnal Riset dan Konseptual, 5(4), 721-730. URL:

https://jurnal.unublitar.ac.id/index.php/ briliant/article/view/542/pdf

Sternberg, R. J., \& Lubart, T. I. (1999). The concept of creativity: Prospects and paradigms.
Handbook of creativity, 1, 3-15. URL: https://psycnet.apa.org/record/199808125-001

Syarifah, E. F., \& Emiliasari, R. N. (2018). Project-based learning to develop students' ability and creativity in writing narrative story. Indonesian EFL Journal, 5(1), 85- 94. doi: 10.25134/ ieflj.v5i1.1627.

Ummah, S. K., In'am, A., \& Azmi, R. D. (2019). Creating manipulatives: improving students' creativity through project-based learning. Journal on Mathematics Education, 10(1), 93-102. https://ejournal.unsri.ac.id/index.php/ jme/article/view/5093/pdf

Zubaidah, S. (2018) Mengenal 4C: Learning and Innovation untuk Menghadapi Era Revolusi Industri 4.0. Article in Pro ceedings "2nd Science Education $\mathrm{Na}$ tional Conference". Universitas Truno joyo, Bangkalan, Madura. Pp. 1-18. 